\title{
РОЛЬ КАТОЛИЦЬКОЇ ЦЕРКВИ В ІДЕОЛОГІЇ ТА ПРАКТИЦІ УСТАШІВ (1930-ТІ - ПЕРША ПОЛОВИНА 1940-Х РР.)
}

\author{
О. Г. Гула
}

Гула О. Г. Роль католицької церкви в ідеології та практиці усташів (1930-ті - перша половина 1940-х рр.). У статті дослідженно роль та місце католицької церкви в усташській ідеології як на початку зародження організації, так і у проголошеній усташами 1941 р. Незалежній державі Хорватія (НДХ). Висвітлено зміну ставлення католицького кліру до усташської діяльності протягом 1930-х - першої половини 1940-х рр. Проаналізовано позицію церкви в питанні проведення етнорелігійної уніфікації в НДХ. На основі залучення до аналізу документів А. Степінаца доведено недоречність однозначного трактування місця та ролі церкви в політиці усташів.

Ключові слова: усташі; НДХ; католицька церква; етнорелігійна уніфікація; радикальний націоналізм.

Гула О. Г. Роль католической церкви в идеологии и практике усташей (1930-е - первая половина 1940-х гг.). В статье исследованы роль и место католической церкви в усташской идеологии, как в начале зарождения организации, так и в провозглашенном усташами в 1941 г. Независимом государстве Хорватия (НГХ). Показано изменение отношения католического клира к усташской деятельности в течение 1930-х - первой половине 1940-х гг. Проанализирована позиция церкви в вопросе проведения этнорелигиозной унификации в НДХ. На основе привлечения к анализу документов А. Степинаца доказана неуместность однозначной трактовки места и роли церкви в политике усташей.

Ключевые слова: усташи; НГХ; католическая церковь; этнорелигиозная унификация; радикальный национализм.

Gula $O$. G. The role of the Catholic Church in the ideology and practice of Ustasha (1930s - early 1940s). The paper researches the role and place of the Catholic Church in ustasha's ideology from the emergence of organization to the proclaiment of the Independent State of Croatia (NDH) in 1941. The change in attitude of the Catholic clergy to activity of ustasha during the $1930 \mathrm{~s}$ - early 1940s is highlighted. The church's position on the issue of ethno-religious unification in NDH is analyzed.Using A. Stepinatz' documents for the analysis the irrelevance of unambiguous interpretation of place and role the Church in the politics of Ustasha is proved.

Keywords: Ustasha; NDH; the Catholic Church; ethno-religious unification; radical nationalism.

Католицька церква завжди відігравала важливу роль у долі хорватського народу. Тривалий час перебуваючи роздрібненими та під владою інших багатонаціональних держав (Італія, Австрія, Угорщина), хорвати навчилися зберігати і відстоювати власну національну ідентичність. Саме католицизм став для них ключовим елементом при підтвердженні окремішності від інших національностей у період існування централізованого Королівства СХС/Югославія (1918-1941рр.). При становленні НДХ (Незалежної держави Хорватія), що стала результатом діяльності профашистської організації усташів і проіснувала 3 1941 до 1945 р., в офіційних документах та заявах політичних діячів римо-католицька віра фігурувала як визначальний чинник належності того чи іншого громадянина до хорватського народу. Саме тому для розуміння внутрішньої політики НДХ необхідно з'ясувати роль католицької церкви у становленні та легітимізації режиму, а також іiі ставлення до етнічних чисток в «незалежній» Хорватії.

Історіографія проблеми почала формуватися одразу після ліквідації НДХ та еміграції прибічників усташів у країни західного світу. Хорватська націоналістична емігрантська історіографія не приділяла суттєвої уваги дослідженню місця католицької церкви в Хорватії 1941-1945 рр. Відмічався великий вплив церкви на формування хорватської національної свідомості, втім клерикальний характер усташської диктатури заперечувався ${ }^{1}$. У соціалістичній Югославії з'явилися перші наукові публікації з даної проблематики. Особливо варто відзначити працю В. Новака «Магнум крімен. Півстоліття клерикалізму в Хорватії» ${ }^{2}$. В цій праці автор узагальнив велику кількість джерел (особливо, матеріали католицької 
преси). Концепція В. Новака була політично детермінована: дослідник намагався виставити хорватський релігійний фанатизм як основний чинник сербофобської політики усташів та інструмент контролю з боку Ватикану над хорватською територією. Подальші наукові розвідки югославських вчених не підтвердили ці погляди, хоча сучасна сербська історіографія загалом продовжує започатковану В. Новаком традицію трактування НДХ як клерофашистської держави ${ }^{3}$. Історіографія проблеми в Республіці Хорватія після 1991 p. вирізняється багатовекторністю порушуваних питань та грунтується на теоретико-методологічному інструментарії хорватської еміграції: применшення масштабів геноциду сербів, виправдання внутрішньої та зовнішньої політики НДХ, тощо ${ }^{4} .1996$ р. у Загребі були опубліковані архівні матеріали стосовно архієпископа А. Степінаца та політики Ватикану в НДХ ${ }^{5}$, що багато в чому ставлять під сумнів концепцію клерофашизму. 3-поміж доробку західних авторів варто відзначити праці А. Рівелі «Архієпископ геноциду» ${ }^{6}$, Д. Бартона «Хорватія 1941-1946»7. Якщо перший з них повністю знаходиться під впливом В. Новака, то другий спробував продемонструвати не лише жорстоку релігійну політику усташів, але й ті позитивні моменти проявів добра, взаємодопомоги, які траплялися у важкий воєнний час. Отже, в історіографії склалось кілька протилежних поглядів на місце католицької церкви в НДХ, що вимагає спроби неупередженого аналізу джерельних свідчень та доробку світової історичної науки.

Католицька церква справді мала велике значення в ідеології усташів. Вона являла собою уособлення національної ідентичності хорватів на противагу православним сербам. Приналежність хорватів до католицької церкви була втіленням приналежності цього народу до європейської цивілізації, що очільниками усташського руху позиціонувалася як прогресивна порівняно з іншими, особливо із православною цивілізацією. Антагонізм між православ'ям та католицизмом мав світоглядне коріння, сутність якого полягала у прагненні католицької церкви збудувати ідеальне суспільство на землі. Своїм корінням такі прагнення сягали римської доби (цезаризм) та були втілені у самій ієрархії католицької церкви, на чолі якої знаходиться одна непогрішима особистість. Спроби перенести подібний устрій на все суспільство періодично траплялись в історії католицизму й раніше (держава ієзуїтів у Парагваї, Іспанія часів реконкісти). У випадку Незалежної держави Хорватія причини такого колосального впливу католицької церкви криються не тільки в тоталітарній сутності іï організації, а й у соціально-економічних чинниках.

У складі Королівства СХС/Югославія хорватські землі були найбільш економічно розвиненим регіоном, адже на цих територіях концентрувалось більше $70 \%$ усієї промисловості країни, а банки Хорватії були тісно пов'язані з фінансовими структурами багатьох інших держав і були найбільшими в Королівстві. Однак це твердження стосувалось насамперед міст, розташованих на Адріатичному узбережжі. Решта території Хорватії та особливо Боснії, що була включена до складу НДХ, належали до сільськогосподарських регіонів. Суспільство зберігало багато традиційних рис, основною з яких був високий авторитет церкви. Політичний устрій Королівства СXC, за якого основні посади в центральній владі обіймали представники сербського народу, призводила до того, що в усіх соціально-економічних негараздах звинувачувалась саме серби, сербська влада. В умовах багатонаціональної держави це призводило до зростання радикального націоналізму.

Хорватський націоналізм зародився ще наприкінці XIX ст. у вигляді Чистої партії права (очолювалась Й. Франком, 31915 р. - А. Павелічем). Утворилась вона внаслідок складного перегрупування Партії права (виникла у 50-х рр. XIX ст.; на чолі партії стояли А. Старчевич і С. Кватерник в середині 80-х pp. ХІХ ст. Виступала за надання Хорватії незалежності на підставі існування в добу сердньовіччя, до початку XII ст., самостійної хорватської держави. Ця політична організація діяла легальними методами, однак вже мала яскраво виражену антисербську спрямованість (що було вельми доречно 3 точки зору австро-угорської зовнішньої політики). Особливістю хорватського націоналізму також була терпимість до євреїв, що пояснювалося єврейським походженням більшості очільників партії Права та усташів. Проте, після проголошення НДХ, репресії проти єврейського населення проводилися дуже активно. Це було спричинене тиском гітлерівської Німеччини на керівництво маріонеткової держави.

Радикалізація хорватського націоналістичного руху припадає на 1929 рік, період встановлення в Королівстві СХС особистої диктатури короля Олександра Карагеоргійовича: 
А. Павеліч, який був прихильником незалежності хорватського народу і виступав проти режиму особистої влади короля Олександра, емігрував до Австрії, потім до Болгарії, а згодом - до Італії, де дістав підтримку у своїй діяльності від Б. Мусоліні. Таким чином майбутній лідер усташів налагоджував зв'язки з тими політиками-емігрантами, котрі підтримували ідею створення незалежної Хорватії. Зокрема, у Відні А. Павеліч зустрівся 3 групою «франківців», серед членів якої виділялись активною діяльністю генерал С. Саркотіч, офіцери колишньої австро-угорської армії І. Перчевіч, С. Дуіч. Саме вони стояли біля витоків широкого руху проти створення Королівства СХС в Австрії і Угорщині, центром якого був Хорватський емігрантський комітет. Очолював його I. Франк, син відомого «франківця» Й. Франка ${ }^{8}$.

Результатом перебування А. Павеліча у Болгарії стала поява «Декларації» про подальшу спільну роботу хорватських і македонських сепаратистів задля встановлення «народних законів» і досягнення політичної свободи Хорватії і Македонії9. Такий порядок справ став відомий Белграду, тому політик мусив залишити Софію і попрямувати до Італії. На Апенінах хорватські усташі на чолі з А. Павелічем на початковому етапі діяльності створювали невеликі військові формування, члени яких здійснювали терористичні акції проти центральної влади в Югославії. Поступово, завдячуючи фінансовій підтримці італійської влади, усташі організували спеціальні табори для проживання і діяльності. Вже у 1929 р. А. Павелічем було створено нову організацію - Усташа - хорватський визвольний рух, до складу якої увійшли хорватські емігранти з різних європейських країн, яких на італійських територіях об’єднала спільна мета.

Головне завдання організації було висвітлено у конституції руху, прийнятій на основі положень програми Чистої партії права - за допомогою збройного повстання визволити хорватські землі для подальшого самостійного і незалежного існування в межах історичних кордонів ${ }^{10}$. Відстоюючи політичні права хорватів, усташі проголошували: «... ми боронитимемо хорватську державну самостійність і боротимемось, щоб у Хорватії панував лише хорватський народ... $\rangle^{11}$. Вони вважали свою боротьбу невідривно пов'язаною з Божим благословінням, адже у Присязі, яку проголошував кожен член руху, звучало: «Клянемось Богом і усім святим, що ... виконуватимемо усі вказівки Поглавника ... та зберігатимемо таємниці ...Нехай допоможе нам Бог!» ${ }^{12}$. Проте, варто зауважити, що на цьому етапі своєї діяльності члени руху не були прихильниками клерикального напряму. Католицька віра сприймалася ними як основна ознака належності до хорватського народу і не більше. На цей же час припадає і широке залучення діячів католицької церкви до хорватського націоналістичного руху. Проводилося це у формі агітаційної роботи зі студентами католицьких навчальних закладів або монахами (переважно францисканцями) - вихідцями із Хорватії. Економічна криза 1930-х рр. підготувала грунт для сприйняття ними праворадикальних ідей ${ }^{13}$.

Усташі взагалі не сприймали панування на Батьківщині сербської влади. Підтвердженням цьому слугує обнародуваний А. Павелічем 1933 р. документ під назвою «Принципи хорватського усташського руху», де зверталась увага на історичне право хорватського народу на проживання у власній незалежній державі, що повинна мати всі складові державності $^{14}$. Автор стверджував, що хорвати завжди були вільним народом, створивши свою державу в час, коли інші народи були роздрібнені і неорганізовані. Хорватська держава завжди забезпечувала добробут своїх громадян, кожен хорват відчував підтримку влади. На особливу увагу заслуговувало селянство як основа всього існування держави ${ }^{15}$. Цим документом усташське керівництво вкотре засвідчило серйозність своїх намірів щодо збройного відстоювання власних прав та виокремлення етнічних хорватських земель у цілісну самостійну державу. Спираючись на підтримку фашистів Італії, хорватські усташі намагались знайти контакти і з Німеччиною для посилення своїх позицій та поширення націоналістичних ідей, але жодне німецьке відомство не звернуло уваги на малочисельну хорватську організацію.

31937 р. почалось поступове повернення хорватських крайніх правих - М. Будака, Ю. Францетіча, Й. Мілковіча та інших - в хорватські землі. Для організації їхньої діяльності голова усташського руху А. Павеліч написав спеціальні «Правила» щодо організації i подальшої діяльності усташських формувань ${ }^{16}$. Документ датований 1938 p., i на його сторінках чітко зазначені головні завдання усташів, методи їхньої боротьби, мету і засоби іiі 
втілення: «...усташі мають завдання усіма засобами ... звільнити Хорватію, щоб вона стала самостійною ... на всьому історичному просторі ${ }^{17}$. Крім того, було прописано склад руху, умови приєднання до нього та організаційну структуру усташських організацій. Таким чином, 3 допомогою цього документа усташський лідер прагнув консолідувати і структуризувати хорватських повстанців, маючи на меті ідею повної незалежності хорватських земель.

31940 р. діяльність усташів активізувалася, що пов'язано було з успішним ходом військових дій їх головних союзників - Італії та Німеччини. Так, в листопаді зі Спліту до керівництва щойно утвореної Хорватської бановини (1939) прийшло повідомлення про необхідність посилення охорони прикордонних з Італією територій у зв'язку з можливою загрозою нападів усташів з їхніх баз, що ймовірно розташовуються у м. Задарі, Лошінь ${ }^{18}$. Тому перед владою автономії постало завдання будь-якими методами (нагляд за кореспонденцією, таємне стеження за особами, які повернулися з-за кордону) попередити діяльність усташів, адже це загрожувало існуванню утвореної напередодні Другої світової війни автономії. Варто зауважити, що розвідка Бановини працювала достатньо добре, адже керівництво мало повну інформацію (дата і місце народження, походження, вид занять, соціальне та матеріальне становище, політичні погляди) про кожного із 839 членів усташських організацій, які перебували на 1940 р. в Італії ${ }^{19}$.

Задля координації та підтримки тих усташів, які підпільно діяли на території Бановини Хорватія, А. Павеліч видав «Повідомлення Батьківщині» ${ }^{20}$, де вказувалось: головною метою організації залишається звільнення країни, запевнивши, що воно втілиться в життя за допомогою союзників. Для таких сподівань були всі підстави: взимку 1940 р. Б. Муссоліні запропонував лідеру усташів А. Павелічу створити спільний план поділу Королівства Югославія, утворивши з частини її територій «незалежну» хорватську державу під італійським протекторатом. На початку березня 1941 р. А. Павеліч виїхав із Флоренції, де проживав останні роки, до Риму для подальших консультацій, а вже 10 квітня, після окупації Югославії військами Осі,очолив уряд НДХ.

Варто зазначити, що за винятком мети здобуття незалежності й заклику до католицького інтегралізму, усташський рух не мав чіткої політичної програми. Цю прогалину заповнив «поглавник» (керманич) в якості диктатора і прем'єр-міністра НДХ шляхом створення «програми намірів»: дії держави повинні бути спрямовані на перетворення Хорватії в батьківщину чистого душею і тілом народу, позбавленого расових сумішей і очищеного від особистостей, далеких його католицькій релігії. Хорватська держава, якою А. Павеліч збирався керувати, налічувала близько шести з половиною мільйонів жителів; 3 них близько двох мільйонів ненависних православних сербів (тобто близько третини населення) $\mathrm{i}$ трохи менше дев'яноста тисяч євреїв ${ }^{21}$.

Справжнім «остаточним рішенням» для усташської диктатури було винищення сербів. Останні вважалися нацією, яка могла «забруднити» «чисту хорватську расу»; це були православні «розкольники», противники римської церкви. Вже 18 квітня поглавник видав перші постанови расистського змісту: вони передбачали призначення державних комісарів на приватні підприємства, що належать сербським або єврейським підприємцям, i конфіскацію всіх їх автотранспортних засобів. Того ж дня було поширено й інше розпорядження Центрального усташського управління (тимчасова назва майбутнього Міністерства внутрішніх справ), яке передбачало «арешт всіх сербів і всіх євреїв, відомих як комуністів, навіть на підставі одних лише підозр» ${ }^{22}$.

Постанова уряду, видана 25 квітня 1941 р., забороняла «використання кирилиці як у приватному, так і в суспільному житті». Через п’ять днів після цього указ «про захист арійської раси і честі хорватського народу» заснував «комісію з расової політики, уповноважену ухвалювати або змінювати рішення у всіх випадках сумнівної расової приналежності». Цим указом передбачалася суспільне розпізнання расово-релігійної приналежності, примусивши сербських громадян носити нарукавну пов'язку синього кольору з літерою «П» (початкова літера слова «православний»), а євреїв носити на рукаві (згодом на спині) зірку Давида ${ }^{23}$.

Після того як всі політичні партії були проголошені незаконними, їх керівники були заарештовані і відправлені в концентраційні табори, що тоді створювалися. Скасовувалась свобода друку: єдиними дозволеними «інформаційними» виданнями були усташські і католицькі газети ${ }^{24}$. Католицька релігія була оголошена «офіційною державною релігією». 
У НДХ мали право голосу лише два органи: усташський уряд і католицька церква. Саме 3 цього періоду усташське керівництво все більше схиляється до клерикалізму як єдино істинного шляху в розвитку національної держави.

Расова програма поглавника була викладена і підтверджена на всіх рівнях, починаючи з вищих кіл усташської влади, при повному мовчанні хорватської католицької церкви. Майбутній міністр закордонних справ Младен Лорковіч, наприклад, 27 липня 1941 р. в місті Доньі Міхольяц заявив наступне: «Усташський рух рішуче прагне до вирішення сербської проблеми в Хорватії. Ті, хто знаходиться по інший бік Сави і Дріни, кричать, що ми нетерпимі, що застосовуємо нелюдські методи щодо сербів. Ми відповідаємо всім, що зобов'язання хорватського уряду зробити так, щоб Хорватія належала тільки хорватам. Наш обов'язок змусити мовчати назавжди ті елементи, які найбільше сприяли потраплянню Хорватії під сербське панування в 1918 р. Одним словом, ми повинні знищити сербів у Хорватії! Це наш обов'язок, і ми це виконаємо. Ми дійдемо до кінця, не звертаючи уваги на те, що говорять по той бік Сави і Дріни про гуманність. Уряд хорватської держави під керівництвом нашого чудового поглавника взяв до своїх вмілих рук рішення цієї проблеми і вирішить їі радикально» ${ }^{25}$.

Усі підрозділи усташських силових структур мали в розпорядженні католицьких священиків; деякі з них, хоча і носили сутану, особисто брали участь у масових вбивствах; інші обмежувалися тим, що виправдовували етнорелігійні масові страти тим, що вони відбувалися «в ім'я Бога». Військових священиків було небагато, і вони підпорядковувалися військовому папському вікарію, тобто А. Степінацу. Підтримка архієпископом А. Степінацем усташської диктатури втілилась також у спробах добитися дипломатичного визнання НДХ з боку Ватикану. Однак де юре цього не вдалося: Ватикан відмовлявся офіційно визнавати державу, з незавершеним військовим конфліктом. Хоча фактичне визнання відбулося - А. Павеліч був прийнятий папою Пієм XII.

Отже, католицька церква як в Хорватії, так і у Ватикані підтримала усташську диктатуру. Католицька газета сараєвского архієпископства від 31 серпня 1941 р. писала: «До сьогоднішнього дня Бог говорив 3 нами за допомогою папських енциклік, проповідей, книг Закону Божого, християнської друку, місій, героїчних прикладів святих. Але вони не слухали. Вони залишилися байдужими. Тепер Бог вирішив використовувати інші методи. Він надихне нас на дії, на виконання загальної місії! Нею будуть керувати не релігійні діячі, а справжні солдати Гітлера. Нарешті проповіді будуть слухатися за допомогою гармат, автоматів, танків і бомбардувальників» ${ }^{26}$. Варто зауважити, що католицькі кола боснійських територій, що стали частиною НДХ, проявляли значно більше радикалізму у своїх висловлюваннях та діях, ніж їхні хорватські однодумці. Пов'язано це було із полірелігійністю місцевого населення, що породжувало постійну конкуренцію між різними конфесіями та бажання утвердити керівною власну релігію.

Хорватська влада активно підтримувала перехід сербів із православ'я до католицизму. А. Степінац вважав розкол християнства прокляттям Європи, в чому його підтримували не лише інші ієрархи католицької церкви, а й очільники НДХ. 30 липня 1941 р. був виданий навіть окремий закон про перехід з православ'я до католицизму. Спеціальну державну комісію, яка з листопада 1941 р. займалася наверненням у католицтво, спочатку очолював особистий капелан А. Павеліча - францисканський священик Діонісій Юріч, а після його смерті в 1943 р. - інший францисканський священик Радослав Главаш. Втім, 17 листопада 1941 р. в Загребі відбулася конференція католицьких архієреїв Хорватії, яка у своїй резолюції з питання переходу сербів у католицтво (мусульмани вважалися хорватами по крові, переведеними у іслам) зазначила: «Щоб поширювати місію Церкви серед народів східного обряду, тільки Церква має право виділяти і направляти місіонерів». Для проведення цієї акції на конференції було обрано раду з трьох членів: архієпископа А. Степінаца, Всенського єпископа В. Бурича і апостольського адміністратора уніатської Кріжевачской єпархії єпископа Я. Шімрака ${ }^{27}$. Перехрещували здебільшого малограмотних селян, адже освічені серби вважалися власне носіями «сербської свідомості» і не могли перетворитися на справжніх хорватів.

Згідно $з$ доповіддю архієпископа А. Степінаца римському папі, на 8 травня 1944 р. 240 тис. сербів перейшло в католицтво. Інші джерела, у тому числі Сербської православної церкви, говорять про приблизно 350 тис. перехрещених за весь період війни (після травня 1945 р. більшість 3 них повернулося в православ'я) $)^{28}$. 
Водночас в особистому спілкуванні з очільниками держави католицькі ієрархи висловлювали невдоволення проведенням етнорелігійної чистки. А. Степінац у листі до А. Павеліча від 24 лютого 1943 р. засудив Ясеновацкій табір «як чорну пляму на репутації незалежної хорватської держави ... і ганьбу всієї Хорватії». А. Степінац, за деякими відомостями, намагався припинити масові вбивства, розуміючи, що вони дискредитують процес «добровільного» переходу сербів у католицтво. Архієпископ неодноразово писав хорватським керівникам, висловлюючи протест проти поголовного знищення сербів. Так, у листі до А. Павеліча від 20 листопада 1941 р. Степінац вказував, що влада заважає Церкві проводити справу переходу сербів в католицтво, зазначаючи: «Видно, що багато сербів переходять у нашу віру, тому що їх змушують, вони перебувають в жаху і страху від жорстокого режиму. Так одна група сербів 3 міста Вировитиця говорила, що їм безпосередньо погрожували смертю і знищенням, якщо вони не відмовляться від православ'я». У червні 1943 р архієпископ навіть публічно виступив проти беззаконних переслідувань православних жителів Хорватії ${ }^{29}$. Особисто Степінац надавав допомогу окремим сербам і євреям, особливо їх дітям; деякі католицькі священики також допомагали православним врятуватися від вбивства.

При цьому Степінац неодноразово виправдовував усташський режим перед папою. Зокрема, у травні 1943 р архієпископ зустрівся з папою і потім сказав новому хорватському посланнику у Ватикані Е. Лобковичу, що на прийомі «мовчав про деякі речі, з якими не зовсім згоден, для того, щоб показати Хорватію в найбільш вигідному світлі» ${ }^{30}$.

Отже, співставлення фактів дає підстави зробити наступні висновки. Ідеологія та внутрішньополітична практика усташського руху зазнавали істотного впливу релігійного фундаменталізму. Вплив цей був спричинений як тією роллю, що відігравала католицька церква в збереженні хорватської національної ідентичності, так і політичними прагненнями очільників усташів за допомогою асоціювання себе із католицькою церквою досягти легітимації політичного режиму, встановленого за допомогою іноземних сил. Без участі останніх усташі не мали шансів на перемогу, підтвердженням чого є невдалі спроби шляхом заслання агентів підняти народне повстання всередині 1930-х рр. В той же час сама католицька церква в особі її вищих ієрархів підтримала становлення НДХ як втілення хорватської національної ідеї. Ставлення церкви до етнорелігійної чистки, що проводилась в НДХ проти сербів та євреїв, було неоднозначним. Окремі діячі повністю підтримували такі дії та навіть особисто брали участь у масових стратах. Позиція вищих ієрархів, зокрема архієпископа А. Степінаца, була більш поміркованою. Вони відкрито не пов'язували себе із подібними акціями, але й не висловлювалися публічно проти них. Лише в особистому спілкуванні з очільниками держави та в щоденниках висловлювалось засудження злочинів проти людяності. На загал же, католицька церква повністю, на всіх рівнях підтримувала курс на етнорелігійну уніфікацію НДХ, часом висловлюючи невдоволення лише методами проведення усташської політики. Основною причиною такої іiі позиції позиції був тісний зв'язок кліру з хорватським національним рухом, що простежується до самого краху режиму 8 травня 1945 p.

${ }^{1}$ Omrčanin I. Croatia 1941-1945. - Washington D.C., 1988. - 432 p.; Jareb J. Pola stoljeća hrvatske politike 1895-1945. - Buenos Aires, 1960. - $180 \mathrm{~s}$.

${ }^{2}$ Novak V. Magnum crimen. Pola vijeka klerikalizma u Hrvatskoj (pretisak). - Beograd: Nova knjiga, 1986. $-1118 \mathrm{~s}$.

${ }^{3}$ Жутић $Н$. Римокатоличка црква и хрватство. Од илирске идеје до великохрватске реализације. 1453-1941. - Београд: Институт за савремену историју,1997. - 336 s.; Джуретич В. Развал Югославии: основные течения 1918-2003 гг. - М.: Кобекс интернешнл, 2003. - 650 с.

${ }^{4}$ Matković H. Povijest Nezavisne Države Hrvatske. - Zagreb: Naklada Pavičić, 2002. - 332 s.; Krišto $J$. Sukob simbola: politika, vjere i ideologije u Nezavisnoj Državi Hrvatskoj. - Zagreb: Nakladni zavod Globus, 2001. $-445 \mathrm{~s}$.

${ }^{5}$ Dokumenti obrane u sudskom procesu protiv nadbiskupa Alojzija Stepinca // Fontes: Izvori za hrvatsku povijest. - Zagreb, 1996. - № 2. -S. 45-463.

${ }^{6}$ Ривели M. Архиепископ геноцида. Монсеньор Степинац, Ватикан и усташская диктатура в Хорватии 1941-1945. - М., 2011.-224 c.

${ }^{7}$ Barton D. Croatia 1941-1946. - URL: www.churchinhistory.org (дата звернення: 23.08.2015).

${ }^{8}$ Jelić-Butić $F$. Prilog proučavanju djelatnosti ustaša do 1941 // Časopis za suvremenu povijest. -1969. - Br. 1-2. - S. 59-60. 
${ }^{9}$ Ibid. - S. 60 .

${ }^{10}$ Hrvatski državni arhiv (далі - HDA) 0249 (GUS). - Glavni ustaški stan, кut. 1, Inv. br. 2592. GUS. Propisnik o zadaći, usrojstvu radu i smjernicama «Ustaša» - Hrvatskog oslobodilačkog pokreta (1941), str. 41.

${ }^{11}$ Ibid, str. 42.

${ }^{12}$ Ustav hrvatske revolucionarne organizacije - Ustasa. - URL: https://hr.wikisource.org/wiki/Ustav hrvatske_revolucionarne_organizacije_Ustas (дата звернення: 23.08.2015).

13 Ривели М. Архиепископ геноцида. Монсеньор Степинац, Ватикан и усташская диктатура в Хорватии 1941-1945. - С. 58.

${ }^{14}$ Jelić-Butić F. Prilog proučavanju djelatnosti ustaša do 1941 // Časopis za suvremenu povijest. - 1969. - Br. 1-2. - S. 62

${ }^{15}$ Matković H. Na vrelima hrvatske povijesti. Dokumenti. - Zagreb: Golden marketing, 2006. S. 323-326.

${ }^{16}$ HDA 0249 (GUS). - Glavni ustaški stan. Inv. br. 2592. GUS. Propisnik o zadaći, usrojstvu radu i smjernicama «Ustaša» - Hrvatskog oslobodilačkog pokreta - 43 lis.

${ }^{17}$ Ibid. - L. 41.

${ }^{18}$ HDA. Banovina Hrvatska.F.155. Kabinet bana. Kut.1, inv.br. 14686/40.

${ }^{19}$ HDA. Banovina Hrvatska.F.155. Kabinet bana. Kut.1, inv.br. 14686/40.

${ }^{20}$ Ustaša. Dokumenti o ustaškom pokretu / Priredio P. Požar. - Zagreb: Zagrebačka stvarnost, 1995. S. 119.

${ }^{21}$ Ривели М. Архиепископ геноцида. Монсеньор Степинац, Ватикан и усташская диктатура в Хорватии 1941-1945. - С. 57.

22 Там же. - C. 61.

${ }^{23}$ Там же. - C. 62.

${ }^{24}$ Matković H. Na vrelima hrvatske povijesti. Dokumenti. - Zagreb: Golden marketing, 2006. S. 376-382.

${ }^{25}$ Ривели М. Архиепископ геноцида. Монсеньор Степинац, Ватикан и усташская диктатура в Хорватии 1941-1945. - С. 76.

${ }^{26}$ Там же. - C. 27.

${ }^{27}$ Novak $V$. Magnum crimen. Pola vijeka klerikalizma u Hrvatskoj (pretisak). - Beograd: Nova knjiga, 1986. - S. 621-622

${ }^{28}$ Шкаровский М. Русская церковная эмиграция и деятельность Хорватской Православной Церкви в 1942-1945 гг. - URL: http://irpz.ru/science/743 (дата звернення: 23.08.2015).

${ }^{29}$ Там же.

${ }^{30}$ Там же. 